\title{
The $\beta 3$ Adrenergic Receptor Agonist BRL37344 Exacerbates Atrial Structural Remodeling Through iNOS Uncoupling in Canine Models of Atrial Fibrillation
}

\author{
Xiaobing Wang ${ }^{\mathrm{a}}$ Ruifeng Wang ${ }^{\mathrm{b}}$ Guangzhong Liua Jingmei Dong ${ }^{\mathrm{a}}$ Guanqi Zhao \\ Jingpu Tian ${ }^{a}$ Jiayu Sun ${ }^{a}$ Xiuyue Jia ${ }^{a}$ Lin Weic Yuping Wang ${ }^{d}$ Weimin Lia
}

\begin{abstract}
a'Department of Cardiology, the First Affiliated Hospital of Harbin Medical University, Harbin, China; bDepartment of Internal Medicine, the Fourth Affiliated Hospital of Harbin Medical University, Harbin, China; 'Department of Cardiology, the First Hospital of Harbin, Harbin, China; ${ }^{\mathrm{d} D e p a r t e n t}$ of Obstetrics and Gynecology, Louisiana State University Health Sciences Center, Shreveport, USA
\end{abstract}

\section{Key Words}

Atrial fibrillation $\bullet \beta 3$-adrenergic receptor - Atrial structural remodeling • Oxidative stress $•$ Nitric oxide synthase $\cdot$ Tetrahydrobiopterin

\begin{abstract}
Background/Aims: The role of the $\beta 3$-adrenergic receptor ( $\beta 3$-AR) agonist BRL37344 in atrial fibrillation (AF) structural remodeling and the underlying mechanisms as a therapeutic target were investigated. Methods: Four groups of dogs were evaluated: sham, pacing, $\beta 3-A R$ agonist BRL37344 ( $\beta 3$-AGO), and $\beta 3$-AR antagonist L748337 ( $\beta 3-A N T)$ groups. Dogs in the pacing, $\beta 3-A G O$ and $\beta 3-A N T$ groups were subjected to rapid atrial pacing for four weeks. Atrial structure and function, AF inducibility and duration, atrial myocyte apoptosis and interstitial fibrosis were assessed. Atrial superoxide anions were evaluated by fluorescence microscopy and colorimetric assays. Cardiac nitrate+nitrite levels were used to assess nitric oxide (NO) production. Protein and mRNA expression of $\beta 3-A R$, neuronal $N O$ synthase (nNOS), inducible NO synthase (iNOS), endothelial NO synthase (eNOS) and guanosine triphosphate cyclohydrolase-1 (GCH-1) as well as tetrahydrobiopterin (BH4) levels were measured. Results: $\beta 3-A R$ was up-regulated in AF. Stimulation of $\beta 3-A R$ significantly increased atrial myocyte apoptosis, fibrosis and atrial dilatation, resulting in increased $A F$ induction and prolonged duration. These effects were attenuated by $\beta 3-\mathrm{ANT}$. Moreover, $\beta 3-\mathrm{AGO}$ reduced $\mathrm{BH} 4$ and NO production and increased superoxide production, which was inhibited by the specific iNOS inhibitor, 1400w. $33-A G O$ also increased iNOS but decreased eNOS and had no effect on nNOS expression in AF. Conclusions: $\beta 3-A R$ stimulation resulted in atrial structural remodeling by increasing iNOS uncoupling and related oxidative stress. $\beta 3-A R$ up-regulation and iNOS uncoupling might be underlying AF therapeutic targets.
\end{abstract}

(C) 2016 The Author(s)

Published by S. Karger AG, Base 


\section{Cellular Physiology Cell Physiol Biochem 2016;38:514-530 \begin{tabular}{ll|l} 
DOI: 10.1159/000438647 & O 2016 The Author(s). Published by S. Karger AG, Basel \\
and Biochemistry Published online: February 01, 2016 www.karger.com/cpb
\end{tabular} \\ Wang et al: $\beta 3$ AR Agonist Contributes to Atrial Fibrillation}

\section{Introduction}

Atrial fibrillation (AF) is the most common self-sustained cardiac arrhythmia closely associated with stroke and heart failure, and its prevalence is rapidly increasing in the aging population [1]. AF is self-perpetuating because AF stimulates atrial electrical, structural and metabolic remodeling [2-4]. Atrial remodeling, in turn contributes to AF development and maintenance, creating a vicious cycle $[5,6]$. After AF cardioversion to sinus rhythm, atrial electrical changes can be completely recovered within a few days, but structural damages may not be fully reversed. Moreover, structural remodeling breaks myocardial continuity, slows electrical conduction, and damages myocardial energy metabolism [4, 7]. Therefore, atrial structural remodeling is vital in AF development as an important substrate. However, the pathophysiology underlying atrial structural remodeling remains poorly understood.

$\beta$-adrenoceptors ( $\beta$-ARs), including $\beta 1, \beta 2$ and $\beta 3$ subtypes, are important modulators in cardiovascular function. $\beta 1$ - and $\beta 2$ - ARs classically mediate the effects of catecholamines on cardiac contraction and vascular smooth muscle relaxation [8]. However, $\beta 3$-AR differs from the $\beta 1$ - and $\beta 2$ subtypes in its molecular structure and pharmacological profile [9]. Although many studies have demonstrated that $\beta 3$-AR upregulation contributes to dysfunction in heart failure $[10,11]$, few reports have described the potential role of $\beta 3-\mathrm{AR}$ in AF. A recent study revealed that $\beta 3$-AR activation induced atrial electrical remodeling in rapid paced atrial myocytes [12], suggesting that $\beta 3$-AR promotes AF development. However, the role of $\beta 3-\mathrm{AR}$ in atrial structural remodeling associated with $\mathrm{AF}$ remains unclear and might present a new therapeutic target.

Oxidative stress is paramount when promoting AF pathogenesis by affecting atrial structural remodeling [13]. Reactive oxygen species (ROS) generated from nitric oxide synthase (NOS) uncoupling may be an underlying contributor [14]. NO is synthesized from L-arginine and oxygen by NOS using tetrahydrobiopterin (BH4) as a cofactor. Under conditions of low BH4 bioavailability relative to NOS, NOS is uncoupled to produce superoxide anion $\left(\mathrm{O}_{2}^{-}\right)$instead of NO (Fig. 1) [14]. There are three isoforms of NOS: neuronal (nNOS), inducible (iNOS), and endothelial (eNOS) [15]. It is well established that negative inotropy associated with $\beta 3$-AR results from the eNOS-NO pathway. However, it remains unclear whether the effect of $\beta 3-A R$ on atrial structural remodeling in AF is related to NOS uncoupling.

Here, we investigated the potential role of $\beta 3-\mathrm{AR}$ in AF canine models induced by rapid atrial pacing and tested the hypothesis that the preferential $\beta 3$-AR agonist BRL37344 exacerbates atrial structural remodeling in AF by increasing oxidative stress from iNOS uncoupling.

\section{Materials and Methods}

Animal Welfare and Ethical Statement

All animal procedures were approved by the Experimental Animal Ethics Committee at the Harbin Medical University. All procedures conformed to the Guide for the Care and Use of Laboratory Animals published by the US National Institutes of Health (NIH Publication No. 85-23, revised in 1996).

Fig. 1. Left: In the process of nitric oxide (NO) production, nitric oxide synthase (NOS) enzymes require the substrates L-arginine and molecular oxygen $\left(\mathrm{O}_{2}\right)$ and the cofactor tetrahydrobiopterin (BH4). Right: Reduced BH4 bioavailability relative to NOS protein results in "uncoupled" NOS characterized by the production of superoxide $\left(\mathrm{O}_{2}^{-}\right)$.

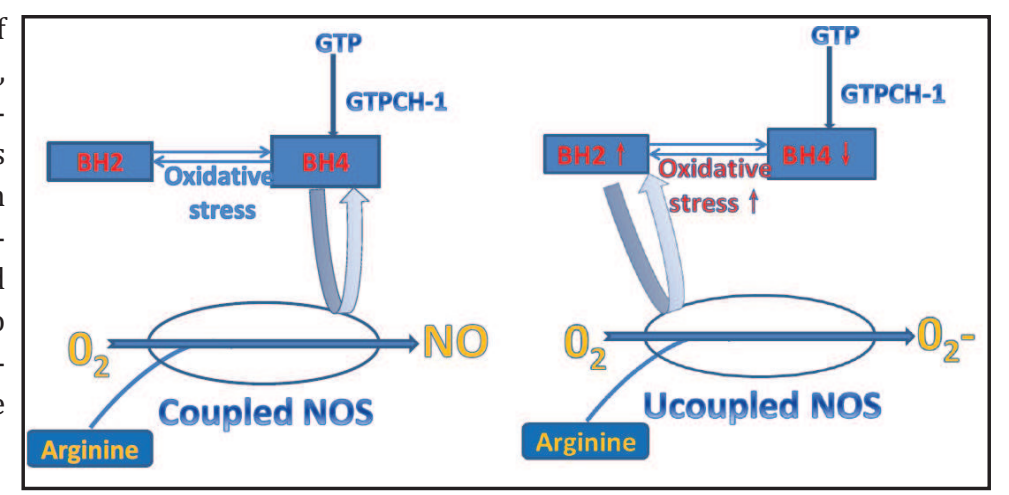




\section{Cellular Physiology Cell Physiol Biochem 2016;38:514-530 \begin{tabular}{ll|l} 
DOI: 10.1159/000438647 & (c) 2016 The Author(s). Published by S. Karger AG, Basel
\end{tabular} and Biochemistry Published online: February 01, 2016 www.karger.com/cpb}

Wang et al.: $\beta 3$ AR Agonist Contributes to Atrial Fibrillation

Animals

A total of 24 male and female mongrel dogs (2 - 3 years of age, 15 - $25 \mathrm{~kg}$ ) were randomized into four groups: sham group (sham surgery) $(n=6)$; pacing group (no drug) $(n=6)$; $\beta 3$-AGO group ( $\beta 3$-AR agonist, BRL37344) ( $\mathrm{n}=6)$; and $\beta 3$-ANT group ( $\beta 3$-AR antagonist, L748337) $(\mathrm{n}=6)$. After adequate anesthesia with sodium pentobarbital ( $25 \mathrm{mg} / \mathrm{kg}$ i.v.), the dogs were rapidly intubated and mechanically ventilated. Thoracotomy was performed from the right fourth intercostal space. A thin silicon lead was implanted into the right atrial free wall and affixed to a pacemaker (Harbin Science and Technology University, China). One week post-surgery, the dogs in the pacing, $\beta 3$-AGO and $\beta 3$-ANT groups were paced at 600 beats per minute (bpm) for four weeks according to a previous study [16]. In the $\beta 3$-AGO and $\beta 3$-ANT groups, the dogs were continuously given an intraperitoneal injection of BRL37344 (1.5 $\mu \mathrm{g} / \mathrm{kg} / \mathrm{h}$, Sigma-Aldrich B169) and L748337 ( $2 \mu \mathrm{g} / \mathrm{kg} / \mathrm{h}$, Sigma-Aldrich L7045), respectively, by an osmotic pump for four weeks during the rapid atrial pacing phase. All experiments were performed in the presence of nadolol, an antagonist for $\beta 1$ - and $\beta 2$-ARs (1 mg/kg, i.p. injection; cat. no. N1892; Sigma-Aldrich). A surface electrocardiogram was recorded daily to ensure sustained atrial pacing at $600 \mathrm{bpm}$.

\section{Echocardiography}

Left atrium (LA) and left atrial appendage (LAA) structure and function were serially assessed by transthoracic and transesophageal echocardiography (Philips 7500, Washington, USA) prior to surgery and heart removal. Parameters related to the LA maximal volume (LAVmax), LAA maximal volume (LAAVmax), LA minimal volume (LAVmin), and LAA minimal volume (LAAVmin) were recorded. The LA ejection fraction was determined as (LAEF) $=($ LAVmax - LAVmin $) /$ LAVmax x 100\%, and the LAA ejection fraction was determined as $($ LAAEF $)=($ LAAVmax - LAAVmin $) /$ LAAVmax $\times 100 \%$.

\section{Electrophysiological assessment of AF}

$\mathrm{AF}$ inducibility and duration were measured at baseline and at the end of the four-week protocol. AF inducibility and duration were assessed using $10 \mathrm{~Hz}$ stimuli (burst pacing at $10 \mathrm{~Hz}$ for $10 \mathrm{~s}$ ) at five-minute intervals with a pacing cycle length of $100 \mathrm{~ms}$. AF was defined as a rapid and irregular atrial rhythm. AF lasting more than 30 minutes was terminated by direct current electrical cardioversion, and the AF duration was recorded for 30 minutes.

\section{Histological analysis of cellular morphometry}

Dogs were anesthetized, and hearts were rapidly excised. Current evidence suggests that the left atrium dominates the occurrence of $\mathrm{AF}[17,18]$. Therefore, left atrial samples adjacent to the left atrium appendage were collected, snap-frozen in liquid nitrogen and then divided into four portions: frozen sections for determination of superoxide $\left(\mathrm{O}_{2} \cdot{ }^{\cdot}\right)$ immediately after excision; tissue fixed with $10 \%$ paraformaldehyde and embedded in paraffin for morphological evaluation; tissue fixed in glutaraldehyde at $4^{\circ} \mathrm{C}$ for electron microscopy; and samples frozen in liquid nitrogen for subsequent assays. Sections $(5 \mu \mathrm{m})$ of the atrium were stained using a Masson trichrome and imaged using light microscopy. The interstitial collagen volume fraction (CVF) was used to evaluate fibrosis. After staining, collagen fibers and cardiomyocytes were stained blue and red, respectively. One section was selected from each sample, and five randomly selected fields from each section were evaluated. The mean area percentage of the collagen fibers was recorded as the collagen volume fraction (CVF\%). Perivascular collagen was not included in the quantification. Sections were evaluated by two professionals who were blinded to the treatment. Digital images were analyzed using Image-Pro Plus 6.0 software.

Ultrathin sections (50 - $100 \mathrm{~nm}$ ) pretreated with gluteraldehyde were prepared for electron microscopy (HITACHI, H7650, Japan) by two observers blinded to the treatments. Sections were prepared according to the method of Zhao et al. [19].

\section{Terminal deoxynucleotidyl transferase-dUTP nick end labeling (TUNEL) analysis}

Tissues embedded in paraffin were sectioned to 7- $\mu \mathrm{m}$ thickness, dewaxed and rehydrated prior to TUNEL staining. TUNEL staining was performed using an In Situ Cell Death Detection kit (Roche Applied Science) according to the manufacturer's instructions. Tissue sections were incubated in $0.1 \mathrm{M}$ citrate buffer and $0.1 \%$ Triton, pH 6.0 , and subsequently exposed to $350 \mathrm{~W}$ of microwave irradiation for 5 minutes. The sections were then rapidly cooled using distilled water $\left(20-25^{\circ} \mathrm{C}\right)$ and rinsed with phosphate buffered saline (PBS) at $15-25^{\circ} \mathrm{C}$. Subsequently, $50 \mu \mathrm{l}$ of TUNEL reaction mixture was added to the sections and 


\section{Cellular Physiology Cell Physiol Biochem 2016;38:514-530 \begin{tabular}{ll|l}
\cline { 2 - 2 } DOI: 10.1159/000438647 & ( ) 2016 The Author(s). Published by S. Karger AG, Basel
\end{tabular} and Biochemistry Published online: February 01, 2016 www.karger.com/cpb \\ Wang et al.: $\beta 3$ AR Agonist Contributes to Atrial Fibrillation}

incubated for 60 minutes at $37^{\circ} \mathrm{C}$. Finally, slides were rinsed three times with PBS. Negative control sections were incubated with $50 \mu \mathrm{l}$ of labeling solution. Positive control sections were incubated with DNAse I (Sigma-Aldrich). Sections were subsequently imaged and microscopically analyzed for TUNEL-positive cells. The percentage of TUNEL-positive nuclei was calculated and recorded as the apoptotic index (AI\%). Five randomly selected fields per section corresponding to approximately 300 cells were examined per treatment condition at high magnification $(200 \mathrm{x})$.

Western blot (WB) analysis of $\beta$-3AR, nNOS, iNOS, eNOS and guanosine triphosphate cyclohydrolase-1 (GCH-1) protein expression

Protein samples were extracted from tissues, and a BCA protein assay kit was used to calculate protein concentrations. A total of $50 \mu \mathrm{g}$ of protein for $\beta$-3AR, iNOS, eNOS and GCH-1 and $150 \mu \mathrm{g}$ protein for nNOS was loaded and separated on SDS gels (8-12\%) followed by blotting onto polyvinylidene difluoride (PVDF) membranes. The membranes were subsequently blocked with $5 \%$ nonfat dry milk in Tris-buffered saline with Tween (TBST) $\left(0.05 \%\right.$ Tween 20 , pH 7.4). Membranes were incubated overnight at $4^{\circ} \mathrm{C}$ with primary antibodies in TBST and subsequently washed in TBST; the membranes were then incubated with horseradish peroxidase (HRP)-conjugated secondary antibodies for 2 hours at $37^{\circ} \mathrm{C}$. The primary antibodies included rabbit anti- $\beta 3$-AR (1:500, Abcam, ab76249), nNOS (1:100, Santa Cruz, sc648), iNOS (1:150, Abcam, ab3523), synthetic peptide corresponding to aa598-612 ( $\left.\mathrm{P}^{598} \mathrm{YNSSPRPEQHKSYK}^{612} \mathrm{C}\right)$ of bovine eNOS (1:1000, Biomol, ALX-210-505) and mouse anti-GCH-1 (1:400,Santa Cruz, sc134574). Glyceraldehyde phosphate dehydrogenase (GAPDH) levels were measured as an internal control with anti-GAPDH (1:1000) antibodies (Abcam, Cambridge, MA, USA). Immunoreactive bands were detected, and the signal intensities were quantified using a chemiluminescent protein detection system (Bio-Rad Laboratories).

Real time polymerase chain reaction (RT-PCR) analysis to detect $\beta 3-A R, n N O S$, iNOS, eNOS and GCH-1 mRNA expression

Total RNA was isolated using Trizol according to the manufacturer's instructions. Reverse transcription was performed in a $20 \mu \mathrm{l}$ reaction mixture with $\mathrm{SYBR}^{\circledR}$ Green qPCR reagents, TaKaRa PrimeScript TM RT reagent Kit and gDNA Eraser (Code No. RR047A) according to the manufacturer's recommendations. Quantitative RT-PCR was performed using an ABI 7500 Real Time PCR system (Applied Biosystems). Canine $\beta 3-A R, n N O S$, iNOS, eNOS, and GCH-1 steady state mRNA levels were measured. Specific primers used to amplify these genes are listed in Table 1. GAPDH was used as an internal control.

Fluorescence measurement of superoxide anion $\left(\mathrm{O}_{2}^{-*}\right)$

The cell-permeable dihydroethidium (DHE) is oxidized to fluorescent hydroethidium (HE) by $\mathrm{O}_{2}{ }^{-}$, which is then intercalated into DNA. The generation of $\mathrm{O}_{2}{ }^{-}$in atrial tissue was determined based on DHE fluorescence, as previously described [20] and according to the manufacturer's instructions (GENMED SCIENTIFICS INC. USA, 10111.2 v. A).

Table 1. Primers for real-time PCR

\begin{tabular}{cll}
\hline \multirow{2}{*}{ beta3-AR } & Forward primer & AGGAGAGGCTTCCAATGTCACCA \\
& Reverse primer & GTCATGTCCAGCACACACCACG \\
nNOS & Forward primer & CTGACGAAGTGGTCCCATGTTT \\
& Reverse primer & GAGTCTCCTCCCTGTAGATGTGGTC \\
\multirow{2}{*}{ iNOS } & Forward primer & GGCTCTACACTTCCAATGTGACCTG \\
& Reverse primer & TTGGACTCTGTAGATTCCGTTGTGA \\
eNOS & Forward primer & CTATCAGACAGACCCGTGGAAGG \\
& $\begin{array}{l}\text { Reverse primer } \\
\text { GCH-1 }\end{array}$ & GGCAGAGATCTTCACCGCATTG \\
& Reverse primer & GTCCTTCACAATCACCATCTCATCA \\
\multirow{2}{*}{ GAPDH } & Forward primer & GTGTCCCCACCCCCAATGTATCAGT \\
& Reverse primer & CAGTGTAGCCCAGGATGCCTTTGAG \\
\hline
\end{tabular}




\section{Cellular Physiology Cell Physiol Biochem 2016;38:514-530 \begin{tabular}{ll|l} 
DOI: 10.1159/000438647 & () 2016 The Author(s). Published by S. Karger AG, Basel
\end{tabular} and Biochemistry Published online: February 01, 2016 www.karger.com/cpb}

Wang et al.: $\beta 3$ AR Agonist Contributes to Atrial Fibrillation

Fresh left atrial samples collected within 1 hour after surgery were placed in ice-cold saline and then embedded for cyrosectioning at the optimal cutting temperature $\left(-20^{\circ} \mathrm{C}\right)$. Each sample was cut into five $10-\mu \mathrm{m}$-thick sections and then placed on glass slides. Sections were washed with $0.5 \mathrm{ml}$ of Reagent A followed by topical application of a DHE stain working solution $(10 \mu \mathrm{M}, 0.2 \mathrm{ml})$. Sections were then incubated for 20 minutes at $37^{\circ} \mathrm{C}$ in a light-protected chamber and subsequently washed with $0.5 \mathrm{ml}$ of reagent $A$ to remove any unbound DHE. Sections were then fixed, secured with a coverslip, and imaged using a laser scanning confocal microscope (ZEISS, LSM510.META). Fluorescence intensity was quantified using Image-Pro Plus 6.0 software.

\section{Colorimetric assay of superoxide anions $\left(\mathrm{O}_{2}^{-}\right)$}

To further measure $\mathrm{O}_{2}^{--}$levels and evaluate the effect of the iNOS inhibitor, $1400 \mathrm{w}$, a colorimetric assay was used to measure $\mathrm{O}_{2}^{-}$in atrial tissues. The assay was performed on fresh left atrial tissues, which were collected within 1 hour after surgery. Canine atrial tissue (50 mg) that was directly adjacent to the LA appendage was used for the assay. Tissues were subsequently homogenized, and proteins were extracted. The extracts were divided into two aliquots (50 $\mu \mathrm{l} \mathrm{each),} \mathrm{and} \mathrm{the} \mathrm{concentrations} \mathrm{were} \mathrm{measured.}$ Nicotinamide adenine dinucleotide phosphate (NADPH) solution (1X) was added to tissue homogenates (one of the $50 \mu \mathrm{l}$ aliquots) after 30 minutes at $4^{\circ} \mathrm{C}$ to a total volume of $1 \mathrm{ml}$, which resulted in a final NAPDH concentration of $100 \mu \mathrm{M}$. The other tissue homogenate (the other $50 \mu \mathrm{l}$ aliquot) was pre-incubated with 100 $\mu \mathrm{M}$ iNOS inhibitor, $1400 \mathrm{w}$ in a total volume of $1 \mathrm{ml}$ for 30 minutes at $4^{\circ} \mathrm{C}$. Staining was performed according to the GENMED Colorimetric assay kit instructions (GENMED SCIENTIFICS INC. U.S.A,10096.2v.A). The optical density (OD) was determined at a wavelength of $580 \mathrm{~nm}$ using a microplate reader. The results were subtracted from the total OD to determine iNOS-dependent $\mathrm{O}_{2} \cdot$ generation.

\section{Measurement of cardiac NO production}

Cardiac NO levels were determined using a two-step measurement of total nitrate+nitrite concentrations and the Nitrate/Nitrite Colorimetric Assay Kit (Cayman Chemical, Ann Arbor, MI, Item No.780001). Atrial tissues (60 mg) were homogenized in PBS at pH 7.4 and subsequently centrifuged at $10,000 \mathrm{x} g$ for 20 minutes. Supernatants were diluted to $6 \mathrm{ml}$ and ultracentrifuged at 100,000 x g for 30 minutes (BECKMAN COULTER, Optima ${ }^{\mathrm{TM}} \mathrm{L}-100 \mathrm{XP}$ Ultracentrifuge). Tissue homogenates $(80 \mu \mathrm{l})$ were generated and used in triplicate. The absorbance of samples was between $0.05-1.2$ absorbance units. A total of $80 \mu \mathrm{l}$ of the tissue homogenate was added to the sample wells, and $200 \mu \mathrm{l}$ of assay buffer was added to blank wells as a negative control. Subsequently, the enzyme cofactor mixture (10 $\mu \mathrm{l})$ and nitrate reductase mixture $(10 \mu \mathrm{l})$ were added to each well (standards and experimental samples). The plate was then incubated at room temperature for 1 hour. Subsequently, Griess Reagent R1 (50 $\mu \mathrm{l})$ and Griess Reagent $\mathrm{R} 2(50 \mu \mathrm{l})$ were added to each of the wells. The color was then allowed to develop for 10 minutes at room temperature. The absorbance was read at $540 \mathrm{~nm}$ using a Bio-Rad iMark ${ }^{\mathrm{TM}}$ microplate reader.

\section{High-performance liquid chromatography (HPLC) for the assessment of BH4}

Atrial tissue $(100 \mathrm{mg})$ was analyzed using HPLC. Tissue was homogenized and diluted to $1000 \mu \mathrm{l}$ prior to processing $(500 \mu \mathrm{l}$ each). Protein concentrations were assessed using the BCA method. Samples $(450 \mu \mathrm{l})$ were incubated with a $50 \mu \mathrm{l}$ acid solution $\left(1.5 \mathrm{M} \mathrm{HClO}_{4}\right.$ and $2 \mathrm{M} \mathrm{H}_{3} \mathrm{PO}_{4}$ mixture of equal proportions) at $4^{\circ} \mathrm{C}$ and subsequently centrifuged at $13,000 \mathrm{~g} / \mathrm{min}$ for 10 minutes. The supernatant ( $450 \mu \mathrm{l}$ ) was transferred to a new Eppendorf tube and incubated with $50 \mu \mathrm{l}$ of acidic iodine solution (1\% iodine $+2 \% \mathrm{KI}$ dissolved in $1 \mathrm{M}$ $\mathrm{HCl})$ at room temperature in the dark for 30 minutes. Subsequently, $25 \mu \mathrm{l}$ of freshly prepared ascorbic acid $\left(20 \mathrm{mg} / \mathrm{ml}\right.$ ) was added at $4{ }^{\circ} \mathrm{C}$ and centrifuged at $13,000 \mathrm{~g} / \mathrm{min}$ for 10 minutes. A portion of the supernatant $(40 \mu \mathrm{l})$ was used to determine the total acid oxidation levels of biopterins (BH4 + $\mathrm{BH} 2+$ biopterin). Simultaneously, $400 \mu \mathrm{l}$ of the same protein extract was incubated with a mixture of $50 \mu \mathrm{l}$ of $1 \mathrm{M} \mathrm{NaOH}$ and $50 \mu \mathrm{l}$ of alkaline iodine ( $1 \%$ iodine $+2 \% \mathrm{KI}$ dissolved in $1 \mathrm{M} \mathrm{NaOH}$ ) in the dark at room temperature for 60 minutes. Subsequently, $100 \mu \mathrm{l}$ of $1 \mathrm{M} \mathrm{H}_{3} \mathrm{PO}_{4}$ and $25 \mu \mathrm{l}$ of a freshly prepared ascorbic acid solution $(20 \mathrm{mg} /$ $\mathrm{ml}$ ) were added to the protein extracts at $4^{\circ} \mathrm{C}$ and centrifuged at $13,000 \mathrm{~g} / \mathrm{min}$ for 10 minutes. A portion of the supernatant $(40 \mu \mathrm{l})$ was then used to measure biopterins that excluded BH4 (BH2 + biopterin). After oxidation (either in acidic or alkaline solution), the sample was immediately used for HPLC analysis. The mobile phase of the HPLC consisted of methanol/water (10/90) at a flow rate of $10 \mathrm{ml} / \mathrm{min}$. Results were obtained by comparison to a standard curve and the results from analytical standards, which were obtained 


\section{Cellular Physiology Cell Physiol Biochem 2016;38:514-530 \begin{tabular}{ll|l} 
DOI: 10.1159/000438647 & O 2016 The Author(s). Published by S. Karger AG, Basel \\
and Biochemistry & Published online: February 01, 2016 www.karger.com/cpb
\end{tabular} \\ Wang et al.: $\beta 3$ AR Agonist Contributes to Atrial Fibrillation}

from Sigma-Aldrich (B-1527 and 37272) and diluted to various concentrations (1, 10, 20, 50 and $100 \mathrm{nM})$. BH4 levels were calculated as the difference between the two measurements (acid and alkaline oxidation) as described by Takeshi and colleagues [21]. Detection of BH4 was assessed by fluorescence detection at excitation and emission wavelengths of $350 \mathrm{~nm}$ and $440 \mathrm{~nm}$, respectively, using a Waters 515 HPLC pump, 717 plus autosamplers, and a 2475 multi $\lambda$ fluorescence instrument.

\section{Statistics}

All data are expressed as the mean \pm standard deviation. Echocardiographic, electrophysiological data and iNOS-dependent $\mathrm{O}_{2} \cdot$ generation were compared using repeated measures analysis of variance (RM-ANOVA). Group data were compared using a one-way ANOVA with a Tukey's post-hoc test for multiple comparisons. A P value of less than 0.05 was considered statistically significant. GraphPad Prism 5.0 and 6.0 (La Jolla, CA) were used for the statistical analysis.

\section{Results}

Upregulation of $\beta 3-A R$ in canine AF models was induced by rapid atrial pacing

RT-PCR analysis and WB results revealed that $\beta 3-A R$ mRNA and protein levels were significantly higher in the pacing group compared to the sham group $(\mathrm{P}<0.01)$. Furthermore, the expression of $\beta 3$-AR mRNA and protein was significantly increased in the $\beta 3$-AR agonist (BRL37344) $\beta 3$-AGO group $(P<0.01$ ) and decreased in the $\beta 3$-AR antagonist (L748337) $\beta 3$ ANT group $(\mathrm{P}<0.05)$ compared to the pacing control group (Fig. 2A, B, C).

Fig. 2. $\beta 3-A R$ mRNA and protein levels in the left atrium. (A) $\beta 3$-AR mRNA expression in the sham, pacing, $\beta 3$-AGO and $\beta 3$-ANT groups. (B) Western bolt analysis of $\beta 3$-AR protein levels using specific $\beta 3$-AR antibodies. GAPDH was used as a loading control. (C) Quantitative analysis of $\beta 3$-AR protein levels relative to GAPDH levels. ${ }^{* *} \mathrm{P}<0.01$ vs. sham group, \#\#P $<0.01$, $\# \mathrm{P}<0.05$ vs. pacing group. $\beta 3$-AGO refers to the $\beta 3$-AR agonist BRL37344 group, and $\beta 3$-ANT refers to the $\beta 3$-AR antagonist L748337 group.

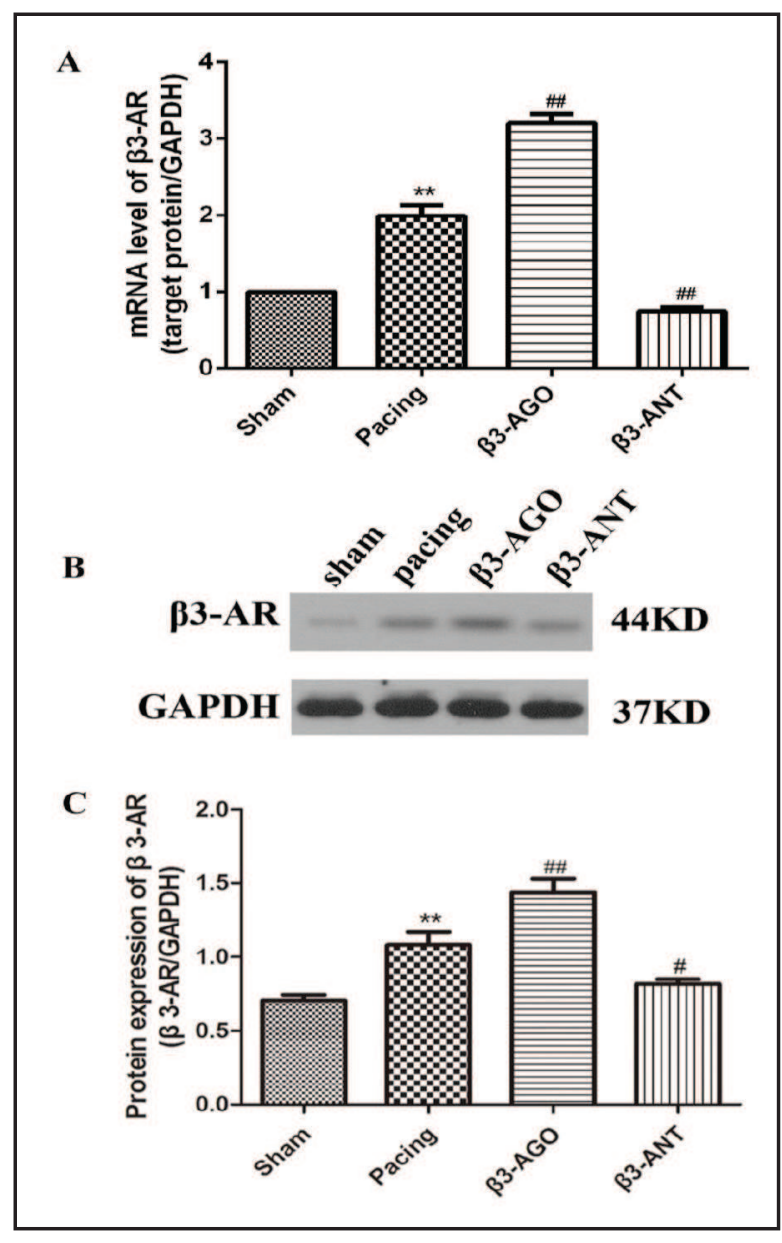




\section{Cellular Physiology Cell Physiol Biochem 2016;38:514-530 \begin{tabular}{ll|l} 
and Biochemistry $10.1159 / 000438647$ & $\begin{array}{l}\text { @ 2016 The Author(s). Published by S. Karger AG, Basel } \\
\text { www.karger.com/cpb }\end{array}$ \\
\hline
\end{tabular} \\ Wang et al.: $\beta 3$ AR Agonist Contributes to Atrial Fibrillation}

Table 2. Electrophysiological evaluation of canine atria before and after rapid atrial pacing. AF cases refer to the number of dogs successfully induced (10 inductions per dog) to develop AF during electrophysiological examination in each group. AF frequency refers to the total number of AF episodes that were induced during electrophysiological examination in all dogs within a group (with the understanding that AF may have been repeatedly induced in the same dog within the scope of its 10 inductions). AF inducibility is calculated as $\mathrm{AF}$ frequency/total stimulations, eg. $60{ }^{*} \mathrm{P}<0.05,{ }^{* *} \mathrm{P}<0.01$ vs. baseline; $\# \mathrm{P}<0.05$, \#\#P $<0.01$ vs. sham group; $\dagger \mathrm{P}<0.05, \uparrow \dagger \mathrm{P}<0.01$ vs. pacing group

\begin{tabular}{|c|c|c|c|c|}
\hline Group & AF cases & $\mathrm{AF}$ frequency & AF inducibility (\%) & AF duration (s) \\
\hline \multicolumn{5}{|l|}{ sham group } \\
\hline baseline & 2 & 8 & 13.33 & $57.83 \pm 15.30$ \\
\hline $\begin{array}{l}5 \text { weeks post-operation } \\
\text { pacing group }\end{array}$ & 2 & 11 & 18.33 & $59.83 \pm 14.63$ \\
\hline baseline & 2 & 8 & 13.33 & $59.50 \pm 17.16$ \\
\hline 4 week pacing & 6 & 50 & $83.33^{* *}$ & $934.17 \pm 191.71^{* * \# \#}$ \\
\hline \multicolumn{5}{|l|}{$\beta 3$-AGO group } \\
\hline baseline & 1 & 7 & 11.67 & $56.50 \pm 28.60$ \\
\hline 4 week pacing & 6 & 59 & $98.33^{* * *}$ & $1276.00 \pm 126.54^{* * *}$ \\
\hline \multicolumn{5}{|l|}{$\beta 3$-ANT group } \\
\hline baseline & 2 & 9 & 15.00 & $54.50 \pm 18.99$ \\
\hline 4 week pacing & 6 & 28 & $46.67^{* * *}$ & $622.00 \pm 135.41^{* *} \ddagger$ \\
\hline
\end{tabular}

$\beta 3$-AR stimulation induced and maintained AF in canines

In the pacing groups, $A F$ inducibility $(P<0.01)$ and duration $(P<0.01)$ were markedly increased compared to the sham group. Moreover, the $\beta 3$-AR agonist (BRL37344; $\beta 3$-AGO) further increased AF inducibility $(\mathrm{P}<0.01)$ and prolonged $\mathrm{AF}$ duration $(\mathrm{P}<0.01)$ compared to the pacing alone group. Interestingly, the $\beta 3-\mathrm{AR}$ antagonist (L748337) significantly inhibited $(\mathrm{P}<0.01) \mathrm{AF}$ induction and maintenance (Table 2).

$\beta 3-A R$ stimulation resulted in atrial dilation and exacerbated atrial dysfunction in the rapid pacing canine model of $A F$

Compared to the sham groups, LAVmax, LAVmin, LAAVmax, and LAAVmin were significantly increased in the pacing group $(\mathrm{P}<0.01)$, while LAEF and LAAEF were decreased $(\mathrm{P}<0.01)$. Compared to the pacing group, the LAVmax, LAVmin, LAAVmax and LAAVmin were significantly increased in the $\beta 3$-AGO group $(\mathrm{P}<0.01)$, while LAEF and LAAEF were decreased $(\mathrm{P}<0.01)$. Interestingly, the $\beta 3-\mathrm{AR}$ antagonist $\mathrm{L} 748337$ abrogated the effects of atrial dilation and dysfunction in the canine pacing model $(\mathrm{P}<0.05)$ (Table 3$)$.

B3-AR stimulation exacerbated atrial myocyte apoptosis and myocardial interstitial fibrosis in the rapid pacing canine model of $A F$

Representative histological staining results are shown in Fig. 3. Compared to the sham group, the percentage of TUNEL-positive cells (apoptosis index, AI) (5.72 $\pm 4.41 \mathrm{vs.} 21.15 \%$ $\pm 12.3 \%, \mathrm{P}<0.01)$ and the CVF $(3.00 \pm 1.18 \%$ vs. $10.29 \pm 1.84 \%, \mathrm{P}<0.01)$ were markedly increased in the pacing group. $\beta 3$-AR stimulation increased atrial myocyte apoptosis $(29.71 \pm$ $10.38 \%$ vs. $21.15 \pm 12.31 \%, \mathrm{P}<0.01)$ and myocardial interstitial fibrosis $(12.88 \pm 3.77 \%$ vs.10.29 $\pm 1.84 \%, P<0.01$ ) compared to the pacing group. In contrast, $\beta 3$-AR inhibition reversed the damage to atrial myocytes $(13.83 \pm 4.61 \%$ vs. $21.15 \pm 12.31 \%, \mathrm{P}<0.01)$ as well as the effects on interstitial fibrosis $(8.01 \pm 2.07 \% v s .10 .29 \pm 1.84 \%, \mathrm{P}<0.01)$.

$\beta 3-A R$ stimulation deteriorated atrial myocardial ultrastructure in the rapid pacing canine model of $A F$

Representative electron micrographs highlighting the ultrastructural changes in the atria are shown in Fig. 4. Atrial myocytes in the sham group presented with regular 


\section{Cellular Physiology Cell Physiol Biochem 2016;38:514-530 \begin{tabular}{ll|l} 
O 2016 The Author(s). Published by S. Karger AG, Basel \\
and Biochemistry $10.1159 / 000438647$ \\
Published online: February 01, 2016 www.karger.com/cpb
\end{tabular} \\ Wang et al.: $\beta 3$ AR Agonist Contributes to Atrial Fibrillation}

Table 3. Atrial dimensions and function in canines before and after a four-week rapid pacing protocol. ${ }^{*} \mathrm{P}<$ $0.05,{ }^{* *} \mathrm{P}<0.01$ vs. baseline, \#\#P $<0.01$ vs. sham group, $\uparrow \mathrm{P}<0.05, \neq \mathrm{P}<0.01 v s$. pacing group. LAV max, LA maximal volume; LAVmin, LA minimal volume; LAEF, LA ejection fraction; LAAVmax, LAA maximal volume; LAAVmin, LAA minimal volume; LAAEF, LAA ejection fraction. 5 weeks refers to 5 weeks post-operation

\begin{tabular}{|c|c|c|c|c|c|c|}
\hline Group & $\begin{array}{l}\text { LAVmax } \\
(\mathrm{ml})\end{array}$ & $\begin{array}{l}\text { LAVmin } \\
(\mathrm{ml})\end{array}$ & $\begin{array}{l}\text { LAEF } \\
(\%)\end{array}$ & $\begin{array}{l}\text { LAAVmax } \\
\text { (ml) }\end{array}$ & $\begin{array}{l}\text { LAAVmin } \\
(\mathrm{ml})\end{array}$ & $\begin{array}{l}\text { LAAEF } \\
(\%)\end{array}$ \\
\hline \multicolumn{7}{|l|}{$\begin{array}{l}\text { sham } \\
\text { group }\end{array}$} \\
\hline baseline & $12.73 \pm 1.26$ & $6.25 \pm 0.84$ & $51.88 \pm 5.55$ & $1.87 \pm 0.21$ & $0.83 \pm 0.14$ & $52.27 \pm 4.84$ \\
\hline $\begin{array}{l}5 \text { weeks } \\
\text { pacing } \\
\text { group }\end{array}$ & $12.88 \pm 1.19$ & $6.33 \pm 0.86$ & $52.42 \pm 4.50$ & $1.92 \pm 0.33$ & $0.91 \pm 0.19$ & $53.10 \pm 4.71$ \\
\hline $\begin{array}{l}\text { baseline } \\
4 \text { week }\end{array}$ & $13.05 \pm 1.11$ & $6.37 \pm 1.12$ & $52.55 \pm 5.19$ & $1.93 \pm 0.31$ & $0.87 \pm 0.14$ & $53.10 \pm 5.03$ \\
\hline $\begin{array}{l}\text { pacing } \\
\beta 3-A G O \\
\text { group }\end{array}$ & $24.47 \pm 1.76^{* * \# \#}$ & $15.57 \pm 1.42^{* * \# \#}$ & $37.27 \pm 5.51^{* * \# \#}$ & $3.10 \pm 0.37^{* * \# \#}$ & $2.15 \pm 0.27^{* * \# \#}$ & $35.77 \pm 4.14^{* * \# \#}$ \\
\hline $\begin{array}{l}\text { baseline } \\
4 \text { week }\end{array}$ & $12.77 \pm 1.13$ & $6.37 \pm 0.94$ & $52.68 \pm 5.13$ & $1.97 \pm 0.21$ & $0.90 \pm 0.19$ & $52.35 \pm 6.22$ \\
\hline $\begin{array}{l}\text { pacing } \\
\beta 3-A N T \\
\text { group }\end{array}$ & $29.37 \pm 1.41^{* * *}$ & $19.32 \pm 1.28^{* * *}$ & $27.58 \pm 4.86^{* *}:$ & $3.85 \pm 0.46^{* *} \neq$ & $2.83 \pm 0.30^{* *} \ddagger$ & $28.22 \pm 1.87^{* * *}$ \\
\hline $\begin{array}{l}\text { baseline } \\
4 \text { week }\end{array}$ & $13.05 \pm 1.17$ & $6.48 \pm 0.97$ & $51.93 \pm 5.12$ & $1.83 \pm 0.26$ & $0.85 \pm 0.15$ & $53.17 \pm 4.91$ \\
\hline pacing & $18.94 \pm 1.50^{* * \neq}$ & $10.08 \pm 1.32^{* * \neq}$ & $45.41 \pm 5.06^{*+}$ & $2.48 \pm 0.32^{*+}$ & $1.28 \pm 0.23^{* * \neq}$ & $44.81 \pm 2.81^{* \ddagger}$ \\
\hline
\end{tabular}

Fig. 3. (A) Assay of apoptosis in the atrial myocardium. T U N E L - pos i tive (apoptotic) nuclei are stained dark brown, while healthy nuclei are stained blue. The magnification is 200 x. (B) Apoptotic index (AI\%) in the atrial myocardium of the sham, pacing, $\beta 3$-AGO and $\beta 3$-ANT groups. (C) Masson's trichrome stain in the atrial myocardium of the sham, pacing, $\beta 3$-AGO and $\beta 3$-ANT groups. Collagen fibers are stained blue, and cardiomyocytes are stained red. The magnification is $200 \mathrm{x}$. (D)

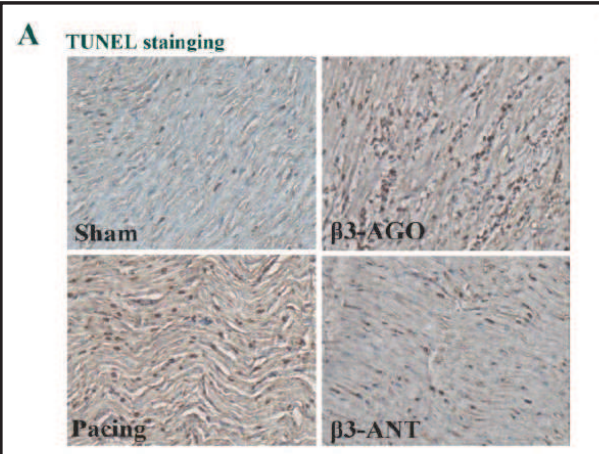

C

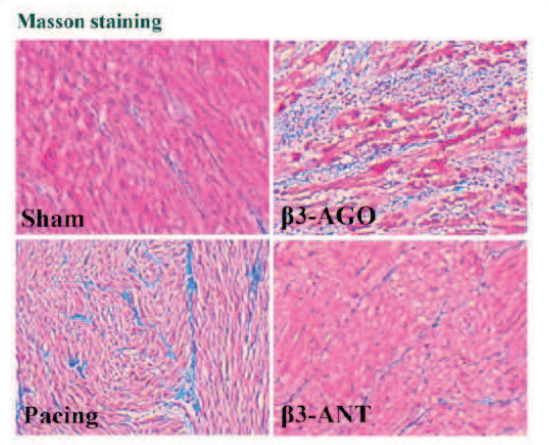

B

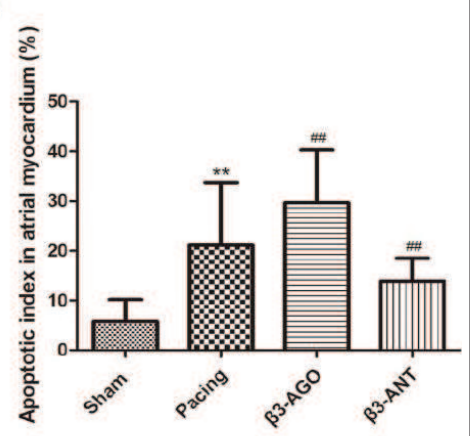

D

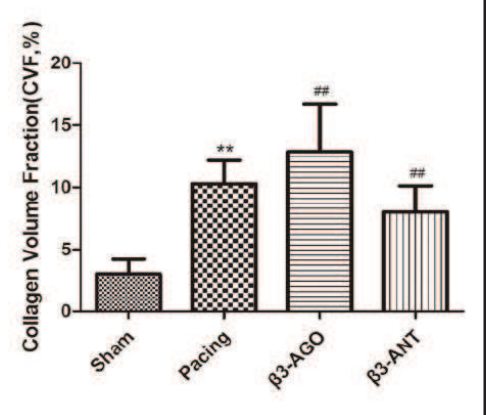

Collagen volume fraction (CVF\%) in atrial myocardium of the sham, pacing, $\beta 3$-AGO and $\beta 3$-ANT groups. Note the increased atrial AI and CVF in the pacing group compared to the sham group. An increase in the AI and CVF was observed in the $\beta 3$-AGO group, whereas a decrease in the AI and CVF was observed in the $\beta 3$ ANT group compared to the pacing group. ${ }^{* *} \mathrm{P}<0.01$ vs. sham group; \#\#P $<0.01$ vs. pacing group. $\beta 3$-AGO refers to the $\beta 3$-AR agonist BRL37344 group, and $\beta 3$-ANT refers to the $\beta 3$-AR antagonist L748337 group.

sarcomere organization and nuclear morphology as well as abundant mitochondria with normal morphology and clear cristae (Fig. 4A). Following the four-week atrial pacing 


\section{Cellular Physiology \\ Cell Physiol Biochem 2016:38:514-530 and Biochemistry

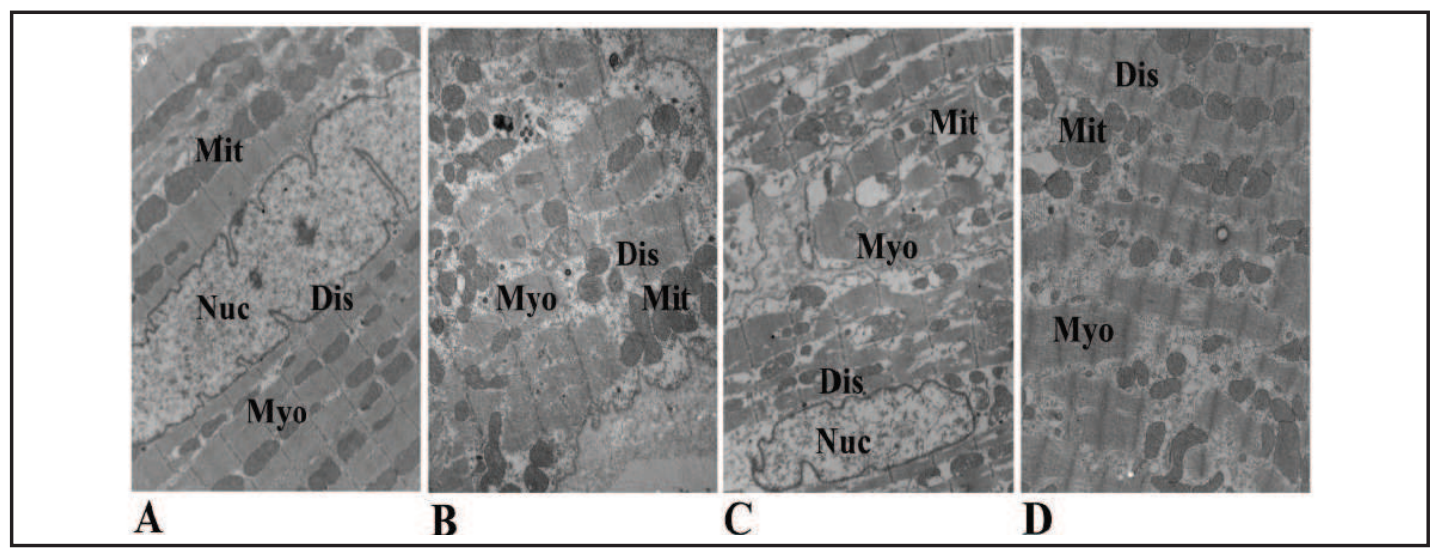

Fig. 4. Electron micrographs of the atrial ultrastructure in the sham, pacing, $\beta 3$-AGO and $\beta 3$-ANT groups. (A) Sham group: Note the regular sarcomere organization, normal nuclear morphology, abundant mitochondria with clear cristae and distinct intercalated discs. (B) Pacing group: Note the disorganized and sparsely arranged myofilaments, mitochondria swelling with decreased cristae and increased interstitial connective tissue. (C) $\beta 3$-AGO group: Note the severe disarray and dissected myofilaments with evident mitochondria swelling and vacuolation as well as increased interstitial connective tissue. (D) $\beta 3$-ANT group: Note the significantly improved ultrastructural changes in atria with limited disorganized myofilaments, mitochondria swelling and fibrous tissue infiltration. The magnification is 8,000x (A,C) and 10,000x (B, D). Mit, mitochondria; Myo, myofilaments; Nuc, nucleus; Dis, intercalated discs. $\beta 3$-AGO refers to the $\beta 3$-AR agonist BRL37344 group, and $\beta 3$-ANT refers to the $\beta 3$-AR antagonist L748337 group.

protocol, ultrastructural damage could be readily observed in the atria and was characterized by sparsely arranged myofilaments that appeared in disarray as well as mitochondria swelling with decreased cristae (Fig. 4B). Moreover, the $\beta 3$-AR agonist BRL37344 worsened the chronic tachypacing-induced ultrastructural defects (Fig. 4C). In contrast, the $\beta 3-\mathrm{AR}$ antagonist L748337 suppressed the ultrastructural damage (Fig. 4D).

$\beta 3-A R$ stimulation increased superoxide anion production and reduced cardiac NO production in the rapid pacing canine model of $A F$

Compared to the sham group, the level of atrial superoxide anion increased in the rapid pacing canine model $(1721.0 \pm 483.5$ a.u. vs. $1161.0 \pm 370.3$ a.u., $\mathrm{P}<0.01)$ (Fig. $5 \mathrm{~A}$ and $\mathrm{B}$ ), suggesting a reaction to oxidative stress. Atrial NO production was decreased in the pacing group $(204.4 \pm 34.36 \mu \mathrm{mol} / \mathrm{g}$ protein $v s .279 .2 \pm 14.09 \mu \mathrm{mol} / \mathrm{g}$ protein, $\mathrm{P}<0.01)$ compared to the sham group, as measured by the sum of the concentrations of the NO metabolites (nitrate and nitrite) (Fig. 5C). In contrast, the $\beta 3$-AR agonist BRL37344 aggravated the atrial oxidative stress, as evidenced by the increase in the superoxide anion level $(2470 \pm 392.5$ a.u. vs. $1721.0 \pm 483.5$ a.u., $\mathrm{P}<0.01)$, as the $\mathrm{NO}$ generation was decreased $(147.7 \pm 16.61$ $\mu \mathrm{mol} / \mathrm{g}$ protein $v s .204 .4 \pm 34.36 \mu \mathrm{mol} / \mathrm{g}$ protein, $\mathrm{P}<0.01$ ) in the pacing canines compared to the pacing group with no drug. Again, the $\beta 3$-AR antagonist L748337 suppressed these biochemical alterations (superoxide anion, $938.5 \pm 232.4$ a.u. vs.1721.0 \pm 483.5 a.u., $\mathrm{P}<0.01$; NO, $248.8 \pm 20.20 \mu \mathrm{mol} / \mathrm{g}$ protein vs. $204.4 \pm 34.36 \mu \mathrm{mol} / \mathrm{g}$ protein, $\mathrm{P}<0.05$ ).

B3-AR stimulation decreased BH4 levels, increased iNOS expression and modulation of $n N O S$ and eNOS in the rapid pacing canine model of AF

We showed that atrial BH4 generation $(0.218 \pm 0.030 \mathrm{pmol} / \mathrm{mg}$ protein vs. $0.118 \pm$ $0.021 \mathrm{pmol} / \mathrm{mg}$ protein, $\mathrm{P}<0.01$ ) (Fig. 5D) and GCH-1 expression (both mRNA and protein) $(\mathrm{P}<0.05)$ (Fig. 6) were decreased in the pacing groups compared to the sham control group. Furthermore, $\beta 3$-AR stimulation reduced atrial BH4 production $(0.050 \pm 0.007 \mathrm{pmol} / \mathrm{mg}$ protein $v s .0 .118 \pm 0.021 \mathrm{pmol} / \mathrm{mg}$ protein, $\mathrm{P}<0.01$ ) (Fig. 5D) and GCH-1 expression $(\mathrm{P}<$ 0.01 ) (Fig. 6) in the pacing $\beta 3$-AGO group, whereas the $\beta 3$-antagonist L748337 attenuated 


\section{Cellular Physiology Cell Physiol Biochem 2016;38:514-530 \begin{tabular}{l|l|l} 
DOI: 10.1159/000438647 & ( 2016 The Author(s). Published by S. Karger AG, Basel
\end{tabular}

A

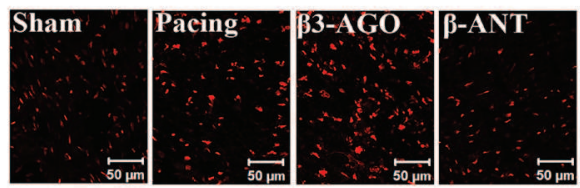

B

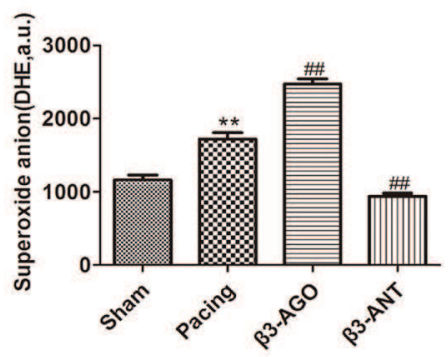

C

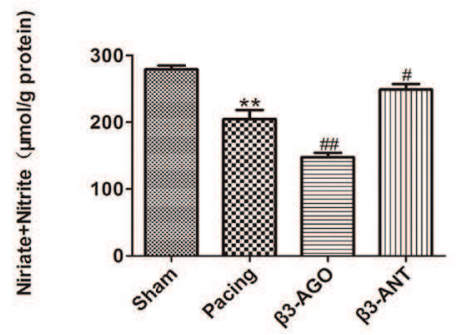

D

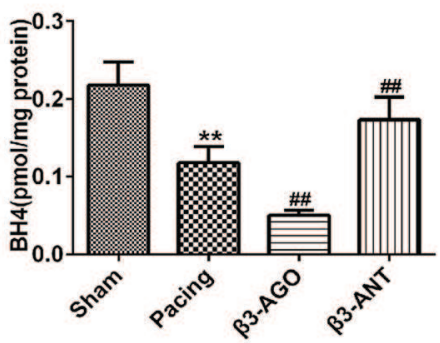

$\mathbf{E}$

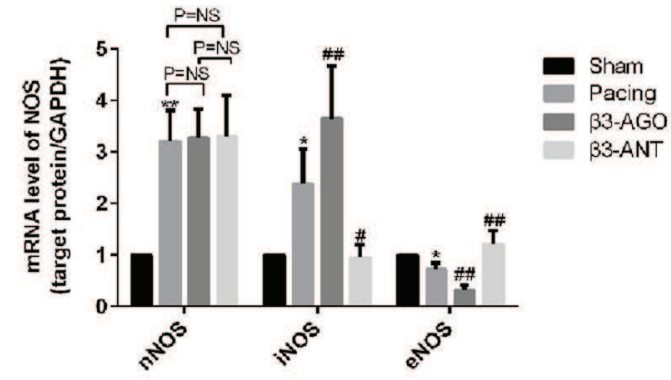

$\mathbf{F}$
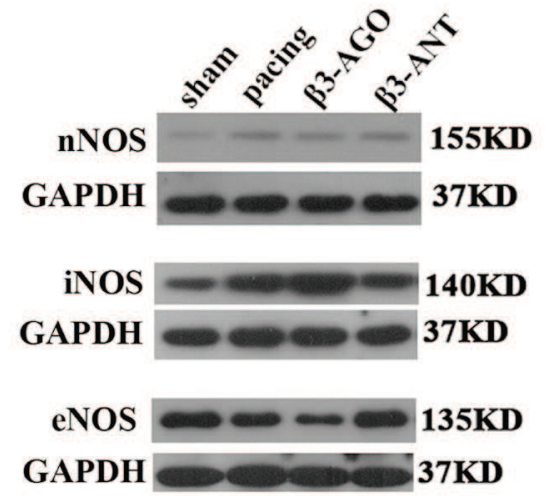

G

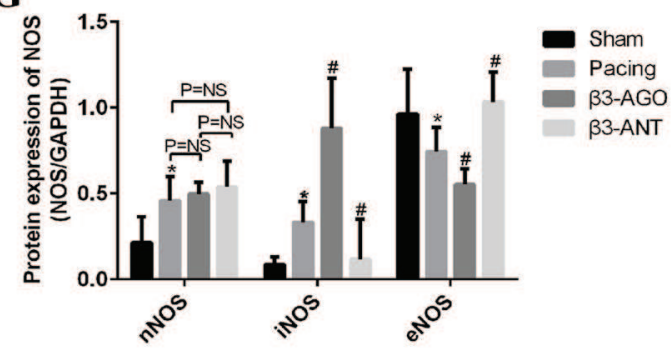

Fig. 5. (A) Representative images of superoxide anion production in the left atrium as assayed based on DHE fluorescence in the sham, pacing, $\beta 3$-AGO and $\beta 3$-ANT groups. Red fluorescence indicates superoxide anion production. (B) Quantitative analysis of superoxide production in the sham, pacing, $\beta 3$-AGO and $\beta 3$-ANT groups. ${ }^{* *} \mathrm{P}<0.01$ vs. Sham group, \#\#P $<0.01$ vs. Pacing group. (C) Nitrate/nitrite represents NO production and was measured by the Griess assay in the sham, pacing, $\beta 3$-AGO and $\beta 3$-ANT groups. ${ }^{* * P}<0.01$ vs. sham group, \#P $<0.05$, \#\#P $<0.01$ vs. pacing group. (D) BH4 levels in the left atria of the sham, pacing, $\beta 3$-AGO and $\beta 3$-ANT groups. ${ }^{* *} \mathrm{P}<0.01$ vs. sham group, $\# \# \mathrm{P}<0.01$ vs. pacing group. $\mathrm{BH} 4$ : tetrahydrobiopterin. (E) nNOS, iNOS and eNOS mRNA expression levels in the sham, pacing, $\beta 3$-AGO and $\beta 3$-ANT groups. $* \mathrm{P}<0.05$ vs. sham group, \#\#P $<0.01$, \#P $<0.05$ vs. pacing group. (F) Western blot analysis of nNOS, iNOS and eNOS expression using specific nNOS, iNOS and eNOS antibodies. (G) nNOS, iNOS and eNOS protein expression in the sham, pacing, $\beta 3$-AGO and $\beta 3$-ANT groups. ${ }^{*} \mathrm{P}<0.05$ vs. sham group, $\# \mathrm{P}<0.05$ vs. pacing group. $\beta 3$-AGO refers to the $\beta 3$-AR agonist BRL37344 group, and $\beta 3$-ANT refers to the $\beta 3$-AR antagonist L748337 group.

these effects $(\mathrm{BH} 4,0.173 \pm 0.029 \mathrm{pmol} / \mathrm{mg}$ protein $v s .0 .118 \pm 0.021 \mathrm{pmol} / \mathrm{mg}$ protein, $\mathrm{P}<0.01$; Fig. 5D) (GCH-1 upregulation by L748337 is shown in Fig. 6; $\mathrm{P}<0.01$ ). 


\section{Cellular Physiology \\ Cell Physiol Biochem 2016;38:514-530 \\ \begin{tabular}{l|l}
\hline DOI: 10.1159/000438647 & (c) 2016 The Author(s). Published by S. Karger AG, Basel
\end{tabular} and Biochemistry \\ Wang et al.: $\beta 3$ AR Agonist Contributes to Atrial Fibrillation}

Fig. 6. GCH-1 mRNA and protein levels in atria of the sham, pacing, $\beta 3$-AGO and $\beta 3$-ANT groups. (A) GCH-1 mRNA levels in atria of the sham, pacing, $\beta 3$-AGO and $\beta 3$-ANT groups. ${ }^{*} \mathrm{P}<0.05$ vs. sham group, $\# \# \mathrm{P}<0.01$ vs. pacing group. (B) Western blot analysis of $\mathrm{GCH}-1$ protein expression in the sham, pacing, $\beta 3$-AGO and $\beta 3$-ANT groups (C) Quantitative analysis of GCH-1 protein in all groups. ${ }^{* *} \mathrm{P}<0.01 v s$. sham group, \#\#P $<0.01$ vs. pacing group. using specific GCH-1 antibodies.

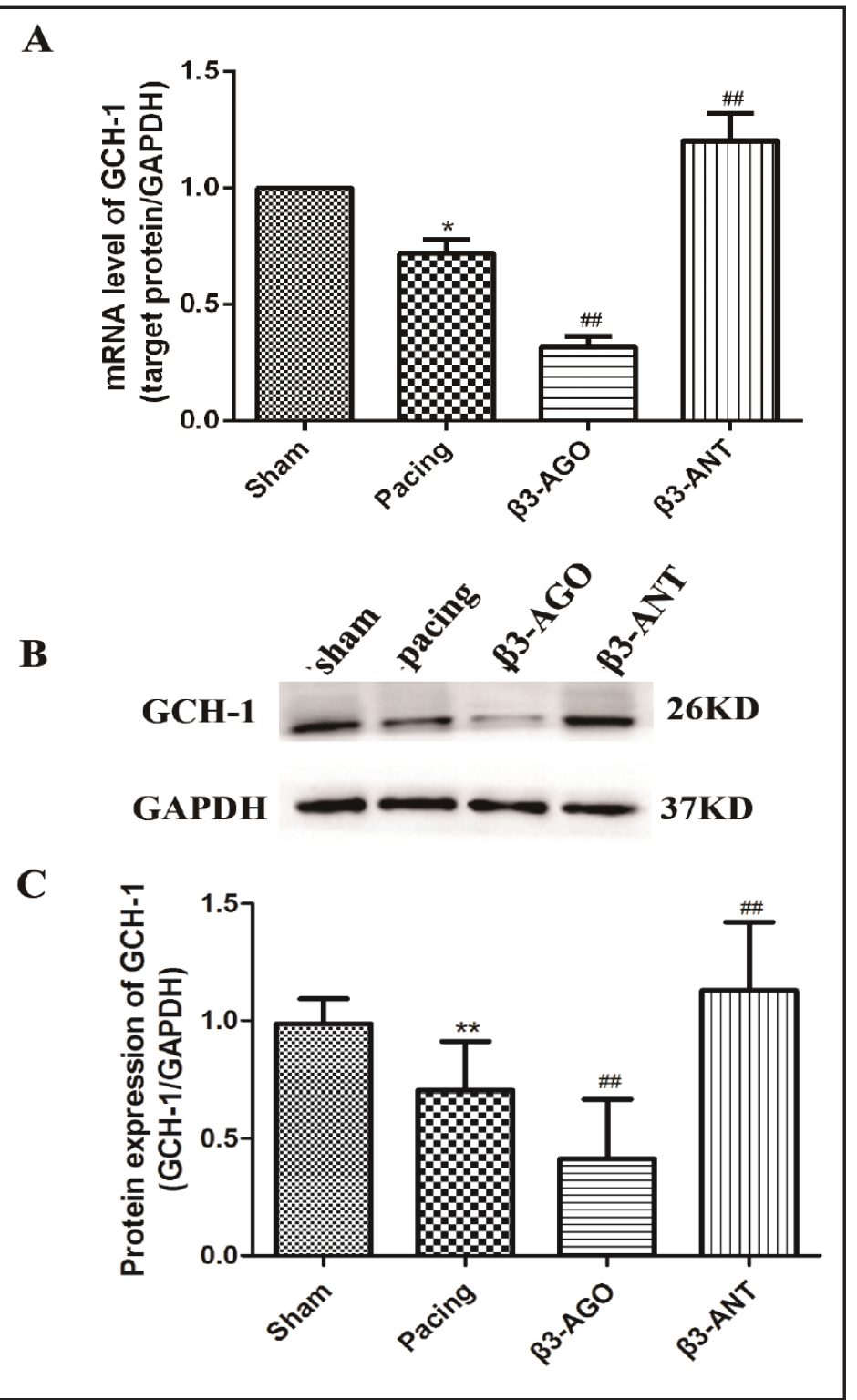

Both iNOS mRNA and protein expression were increased in the pacing group compared to the sham group ( $P<0.05$ ) (Fig. 5E, F and G). iNOS expression was also increased by the $\beta 3-A R$ agonist and suppressed by the $\beta 3-A R$ antagonist in the pacing groups compared to pacing alone $(\mathrm{P}<0.05)$.

We further demonstrated that nNOS expression (mRNA and protein) was increased (P $<0.05)$ and eNOS (mRNA and protein) expression was decreased $(\mathrm{P}<0.05)$ in the pacing groups compared to the sham group (Fig. 5E, F, and G). Parallel to other findings, the $\beta 3$ AR agonist BRL37344 markedly reduced eNOS expression $(P<0.05)$, whereas the $\beta 3$ AR antagonist $\mathrm{L} 748337$ reversed these effects $(P<0.05)$ (Fig. 5E, F, and G). Interestingly, nNOS levels did not vary among the pacing groups in the presence of the $\beta 3-\mathrm{AR}$ agonist and antagonist ( $P>0.05$ ) (Fig. 5E, F, and G).

$\beta 3$-AR stimulation resulted in superoxide anion generation, which could be decreased by the specific iNOS inhibitor

Using a superoxide colorimetric assay, we demonstrated that atrial homogenates had increased superoxide production in the $\beta 3$-AR agonist group $(0.064 \pm 0.008 \mu \mathrm{mol} / \mathrm{mg}$ protein vs. $0.099 \pm 0.024 \mu \mathrm{mol} / \mathrm{mg}$ protein, $\mathrm{P}<0.01$ ) and that these effects were inhibited in the $\beta 3$ - 


\section{Cellular Physiology \\ Cell Physiol Biochem 2016;38:514-530 \\ \begin{tabular}{l|l}
\hline DOI: $10.1159 / 000438647$ & (c) 2016 The Author(s). Published by S. Karger AG, Basel
\end{tabular} and Biochemistry Published online: February 01, 2016 www.karger.com/cpb \\ Wang et al.: $\beta 3$ AR Agonist Contributes to Atrial Fibrillation}

Fig. 7. Quantitative analysis of superoxide anion production in the sham, pacing, $\beta 3$-AGO and $\beta 3$-ANT groups using a colorimetric assay. (A) Comparisons of superoxide levels were directly assayed after tissue collection in the sham, pacing, $\beta 3$-AGO and $\beta 3$-ANT groups and after incubation with the iNOS inhibitor $1400 \mathrm{w}$. ** $\mathrm{P}<0.01$. (B) Comparisons of total superoxide levels amongst all groups. The results were subtracted from the total levels to obtain the iNOS-dependent superoxide levels. ${ }^{* *} \mathrm{P}<0.01$ vs. sham group, \#\#P $<0.01$ vs. pacing group.

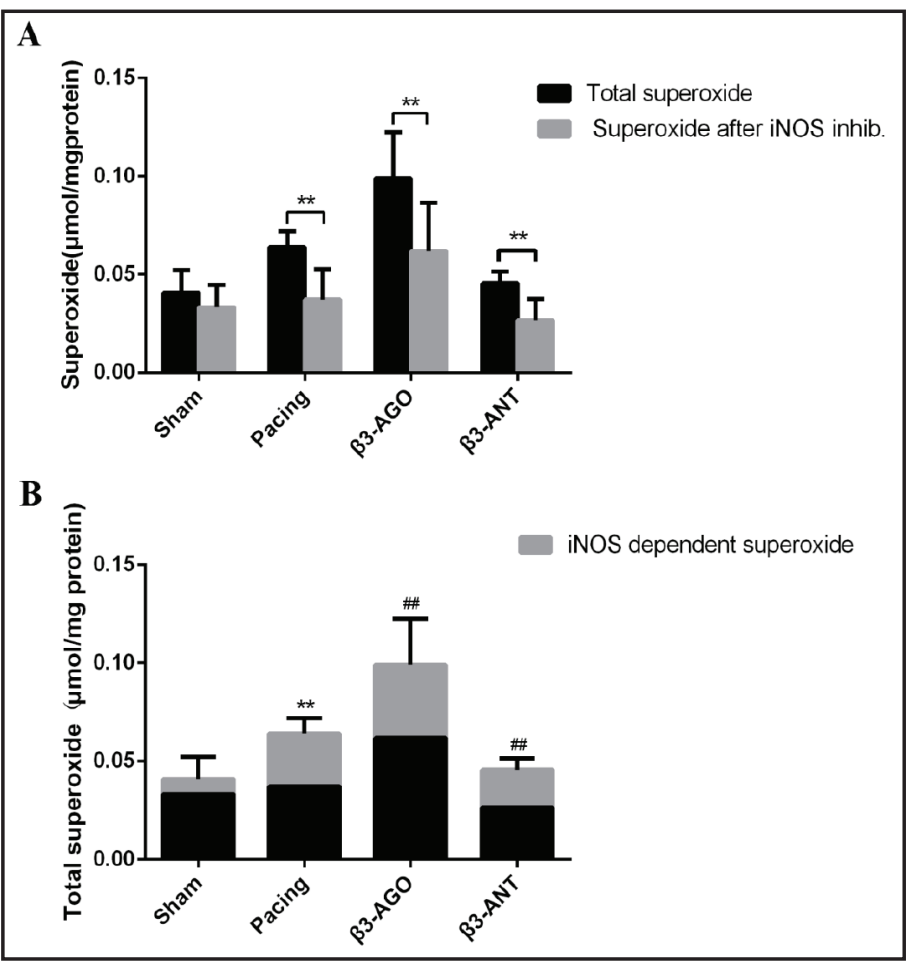

AR antagonist group $(0.046 \pm 0.006 \mu \mathrm{mol} / \mathrm{mg}$ protein vs. $0.064 \pm 0.008 \mu \mathrm{mol} / \mathrm{mg}$ protein, $\mathrm{P}<$ 0.01 ) (Fig. 7), which was consistent with the DHE fluorescence results (Fig. 5B). Interestingly, pretreatment of the atrial homogenates with $100 \mu \mathrm{M}$ of the specific iNOS inhibitor 1400W abolished the increase in superoxide production observed with $\beta 3$-AR agonist stimulation $(0.062 \pm 0.025 \mu \mathrm{mol} / \mathrm{mg}$ protein $v s .0 .099 \pm 0.024 \mu \mathrm{mol} / \mathrm{mg}$ protein, $\mathrm{P}<0.01)$ (Fig. 7).

\section{Discussion and Conclusions}

This present study revealed for the first time that $\beta 3$-AR activation exacerbates atrial structural remodeling by activating iNOS uncoupling/oxidative stress, which could be considered a novel therapeutic target for AF.

B3-ARactivation promoted AF by aggravating atrial structural remodeling and dysfunction

$\beta 3$-AR belongs to a group of $\mathrm{G}$ protein-coupled receptors characterized by seven transmembrane domains having features that determine their resistance to long-term downregulation and significance in regulating cardiac performance following acute and chronic stress. $\beta 3$-AR levels were upregulated, which aggravated cardiac dysfunction during heart failure $[10,11]$. Additionally, in humans and dogs, $\beta 3-A R$ is detected in lung and peripheral arteries and causes vasodilation $[22,23]$. Therefore, $\beta 3$-AR had beneficial effects in perinephritic hypertension [24]. Meanwhile, $\beta 3$-AR stimulation has antiarrhythmic effect in canine ventricular tachycardia [25]. Different levels of $\beta 3$-AR in the cardiac chambers at different stages of the pathologies and various downstream pathways may determine the functional characterization of $\beta 3$-AR in different cardiovascular diseases.

In our study, we observed an upregulation of $\beta 3-\mathrm{AR}$ in $\mathrm{AF}$ canines induced by rapid atrial pacing. $\beta 3$-AR stimulation further increased atrial apoptosis and interstitial fibrosis, indicative of an exacerbation of atrial structural remodeling. Atrial structural remodeling in turn promotes AF development and self-persistence. Apoptosis and interstitial fibrosis during atrial structural remodeling are both considered potential therapeutic targets for AF [26-31]. Subsequent apoptosis and reparative fibrosis replaces dead cardiomyocytes, which 


\section{Cellular Physiology Cell Physiol Biochem 2016;38:514-530 \begin{tabular}{ll|l} 
DOI: 10.1159/000438647 & O2016 The Author(s) \\
and Biochemistry Published online: February 01, 2016 & www.karger.com/cpb \\
\cline { 2 - 3 }
\end{tabular} \\ Wang et al.: $\beta 3$ AR Agonist Contributes to Atrial Fibrillation}

interrupts fiber bundle continuity, thereby slowing conduction [29, 32, 33]. Therefore, atrial structural remodeling has a strong impact on electrical remodeling. Our study also indicated that $\beta 3-\mathrm{AR}$ activation increased AF inducibility and prolonged AF duration, which might be associated with the exacerbating effect of $\beta 3-A R$ on atrial structural remodeling. Yu and colleagues recently highlighted that $\beta 3-\mathrm{AR}$ activation promotes atrial electrical remodeling by decreasing the abundance of L-type calcium channels as well as increasing the inward rectifier potassium current $\left(\mathrm{I}_{\mathrm{K} 1}\right)$ and transient outward potassium current $\left(\mathrm{I}_{\mathrm{to}}\right)$ in acute AF models of rabbit and atrial myocytes [12]. Furthermore, Liu et al. recently demonstrated that $\beta 3$-AR activation disturbed cardiac energy metabolism and aggravated AF in a rabbit AF model [34]. Moreover, in this present study, therapies using the $\beta 3$-AR antagonist L748337 attenuated atrial apoptosis and interstitial fibrosis in AF canines, which prevented AF development.

Generally, atrial dilatation enhances cardiac vulnerability to AF, which in turn results in progressive atrial dilatation. Therefore, $\mathrm{AF}$ and atrial dilatation are mutually promoting and constitute a vicious circle. Atrial dilatation results in contractile dysfunction associated with typical features of AF [35]. Atrial size is a key determinant of AF reentry [36]. Therefore, therapies targeted at reducing atrial size may prevent AF. Treatment with the $\beta 3-\mathrm{AR}$ antagonist L748337 in our AF model resulted in decreased atrial volume and attenuation of impaired atrial function, which was effective in preventing AF.

\section{$\beta 3$-AR activation increased iNOS uncoupling and oxidative stress}

Oxidative stress is a major underlying pathology that promotes AF [13]. Excess ROS can result in a loss of enzyme function, mitochondrial dysfunction and cellular death, all of which strongly correlate with atrial structural remodeling [13]. Thus, inhibition of cardiac ROS may be effective in circumventing AF. Of the numerous cellular sources of ROS, uncoupled NOS is the major source in the human heart [13,37].

NOS uncoupling is involved in many pathologies, such as diabetes mellitus, hypertension, ageing, and atherosclerosis [38], all of which were associated with AF. In the process of NO production, the L-arginine concentration does not affect the reaction [39-41], although low BH4 bioavailability relative to NOS results in uncoupled NOS and excessive superoxide production [14]. In this present study, we observed a decrease in BH4 levels, an increase in atrial myocardial superoxide anion levels and a decrease in NO production by $\beta 3$-AR stimulation in the AF canine model. This indicates that $\beta 3$-AR activation induces NOS uncoupling and oxidative stress.

We measured endogenous changes in the three isoforms of NOS following $\beta 3$-AR stimulation in $\mathrm{AF}$ canines to investigate which isoform dominated the effects of $\beta 3-\mathrm{AR}$ on NOS uncoupling. The heart normally expresses the constitutive enzymes nNOS and eNOS, whereas iNOS is inducibly expressed in pathological states [15, 42]. Additionally, iNOS is closely associated with inflammation [15] and oxidative stress [37], both of which are involved in the atrial structural remodeling in AF [43]. Han and colleagues also reported that iNOS protein levels are increased in the atria of patients with permanent AF [44].

$\beta 3$-AR mediates negative inotropic effects on the ventricular myocardium by eNOS activation $[45,46]$. In contrast, $\beta 3$-AR activation increases the contractility of the human right atrium [45]. Moreover, we revealed that BRL37344 inhibited eNOS expression in the atrium of $\mathrm{AF}$ canines. Different effects of $\beta 3-\mathrm{AR}$ on the atria and ventricle occur potentially due to lower $\beta 3$-AR expression in the atria [47] and different activation mechanisms of $\beta 3$ AR on eNOS [48]. Additionally, $\beta 3$-AR activation mediated anti-hypertrophic and antioxidant effects on hypertrophic ventricular cardiomyocytes via a nNOS-dependent mechanism [49]. In contrast, our data revealed that BRL37344 activated iNOS but did not influence nNOS levels in the AF canine model. Moreover, the specific iNOS inhibitor 1400W abolished the induction of superoxide production by the agonist of $\beta 3-\mathrm{AR}$, which validated our previous hypothesis. Consequently, mediation of different signaling pathways may determine the diverse performance of $\beta 3$-AR in atria and ventricles. Therefore, $\beta 3$-AR stimulation aggravated atrial oxidative stress, which likely resulted from iNOS activation. The importance of iNOS was 


\section{Cellular Physiology \\ Cell Physiol Biochem 2016;38:514-530 \\ \begin{tabular}{l|l}
\hline DOI: 10.1159/000438647 & (c) 2016 The Author(s). Published by S. Karger AG, Base
\end{tabular} and Biochemistry Published online: February 01, 2016 www.karger.com/cpb \\ Wang et al.: $\beta 3$ AR Agonist Contributes to Atrial Fibrillation}

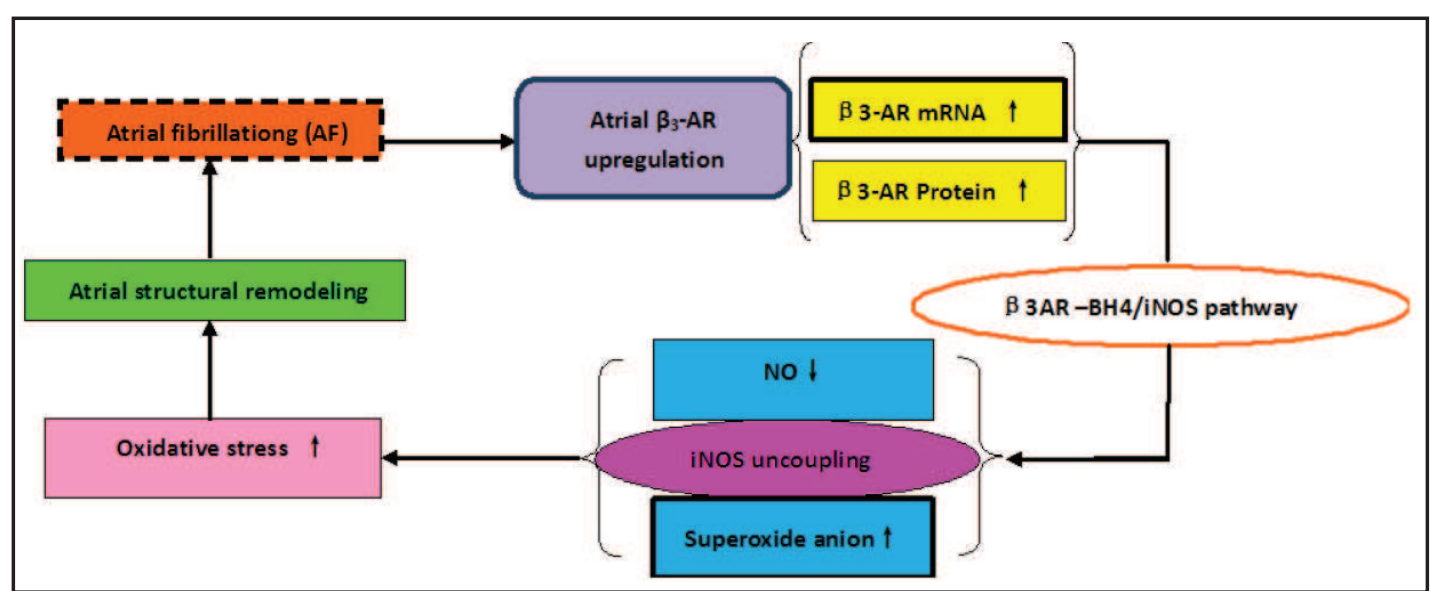

Fig. 8. Schemata of the mechanisms underlying the role of $\beta 3$-AR stimulation in atrial structural remodeling associated with AF.

further validated by our $\beta 3$-AR antagonist, L748337, which reversed the aberrant expression of NOS isoforms.

BH4 is synthesized from guanosine triphosphate (GTP) by GTP cyclohydrolase, with GCH-1 acting as the rate-limiting enzyme [14]. Therefore, BH4 concentrations strongly correlate with GCH-1 expression. This present study showed that BH4 down-regulation by BRL37344 may occur due to reduced levels of GCH-1. Animal studies have confirmed that BH4 supplementation can reduce oxidative stress [50] and attenuate cardiac remodeling post-infarction [51]. However, due to the high cost and poor feasibility of BH4 in clinical practice, it is not utilized here in this study. $\beta 3$-AR inhibition with L748337 in this study increased GCH-1 and BH4 levels, indicating a more feasible therapy for reducing atrial oxidative stress and structural remodeling in $\mathrm{AF}$.

In conclusion, our study demonstrates that $\beta 3$-AR activation triggers a cascade of events resulting in atrial structural remodeling (Fig. 8), and these effects might be partially attributed to iNOS uncoupling and oxidative stress in AF.

\section{Clinical implications}

The $\beta 3$-AR antagonist L748337 was clearly effective in suppressing the progression of atrial structural remodeling, and the specific iNOS inhibitor attenuated atrial oxidative stress. Thus, both mediators have an important effect on the arrhythmogenic substrate for $\mathrm{AF}$ and could have therapeutic roles in clinical practice. Therefore, this present study revealed two targets for AF treatment.

\section{Abbreviations}

AF (Atrial fibrillation); AI (Apoptotic index); B (Biopterin); BH4 (Tetrahydrobiopterin); BH2 (Dihydrobiopterin); DHE (Cell-permeable dihydroethidium); $\beta 3$-AR ( $\beta 3$ adrenergic receptor); $\beta 3$-AGO ( $\beta 3$ adrenergic receptor agonist); $\beta 3$-ANT ( $\beta 3$ adrenergic receptor antagonist); CVF (Collagen volume fraction); eNOS (Endothelial NOS); GCH-1 (Guanosine triphosphate cyclohydrolase-1); HPLC (High-performance liquid chromatography); HE (Hydroethidium); HRP (Horseradish peroxidase); iNOS (Inducible NOS); LA (Left atrium); LAA (Left atrial appendage); LAVmax (LA maximal volume); LAAVmax (LAA maximal volume); LAVmin (LA minimal volume); LAAVmin (LAA minimal volume); LAEF (LA ejection fraction); LAAEF (LAA ejection fraction); NO (Nitric oxide); nNOS (Neuronal NOS); NOS 


\section{Cellular Physiology Cell Physiol Biochem 2016;38:514-530

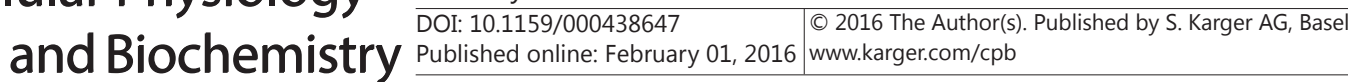 \\ Wang et al.: $\beta 3$ AR Agonist Contributes to Atrial Fibrillation}

(Nitric oxide synthase); NADPH (Nicotinamide adenine dinucleotide phosphate); ROS (Reactive oxygen species); TBST (Tris-buffered saline and tween 20); WB (Western blot); PVDF (Polyvinylidenedifluoride); $\mathrm{O}_{2}^{-}$(Superoxide anion).

\section{Acknowledgements}

This work was supported by the National Natural Science Foundation of China (grant numbers: 81270252, 30971251, 81070160 and 81100071), the Foundation for Innovative Research Groups of the National Natural Science Foundation of China (81121003), the Scientific Research Fund of Heilongjiang Provincial Education Department (grant number 12521206) and grants from the Science and Research Foundation of the First Hospital of Harbin.

\section{Disclosure Statement}

The authors declare that they have no conflicts of interest.

\section{References}

1 Camm AJ, Lip GY, De Caterina R, Savelieva I, Atar D, Hohnloser SH, Hindricks G, Kirchhof P: 2012 focused update of the ESC Guidelines for the management of atrial fibrillation: an update of the 2010 ESC Guidelines for the management of atrial fibrillation. Developed with the special contribution of the European Heart Rhythm Association. Eur Heart J 2012;33:2719-2747.

2 Krogh-Madsen T, Abbott G, Christini D: Effects of electrical and structural remodeling on atrial fibrillation maintenance: a simulation study. PLoS Comput Biol 2012;8:e1002390.

3 Liu L, Geng J, Zhao H, Yun F, Wang X, Yan S, Ding X, Li W, Wang D, Li J, Pan Z, Gong Y, Tan X, Li Y: Valsartan reduced atrial fibrillation susceptibility by inhibiting atrial parasympathetic remodeling through MAPKs/ Neurturin pathway. Cell Physiol Biochem 2015;36:2039-2050.

4 Liu Y, Geng J, Yang LSB, Liu Y, Li Y, Cheng C, Shen J, Li W: $\beta 3$-adrenoceptor mediates metabolicprotein remodeling in a rabbit model oftachypacing-induced atrial fibrillation. Cell Physiol Biochem 2013;32:16311642.

5 Iwasaki Y-k, Nishida K, Kato T, Nattel S: Atrial fibrillation pathophysiology: Implications for management. Circulation 2011;124:2264-2272.

6 Tan AY, Zimetbaum P: Atrial fibrillation and atrial fibrosis. J Cardiovasc Pharmacol 2011;57:625-629.

7 Dong J, Zhao J, Zhang M, Liu G, Wang X, Liu Y, Yang N, Liu Y, Zhao G, Sun J, Tian J, Cheng C, Wei L, Li Y, Li W: $\beta 3$-adrenoceptor impairs mitochondrial biogenesis and energy metabolism during rapid atrial pacinginduced atrial fibrillation. J Cardiovasc Pharmacol Ther 2016;21:114-126.

8 Gauthier C, Rozec B, Manoury B, Balligand J-L: Beta-3 adrenoceptors as new therapeutic targets for cardiovascular pathologies. Curr Heart Fail Rep 2011;8:184-192.

9 Gauthier C, Sèze-Goismier C, Rozec B: Beta 3-adrenoceptors in the cardiovascular system. Clin Hemorheol Microcirculat 2007;37:193-204.

10 Moniotte S, Kobzik L, Feron O, Trochu JN, Gauthier C, Balligand JL: Upregulation of beta(3)-adrenoceptors and altered contractile response to inotropic amines in human failing myocardium. Circulation 2001;103:1649-1655.

11 Cheng HJ, Zhang ZS, Onishi K, Ukai T, Sane DC, Cheng CP: Upregulation of functional beta(3)-adrenergic receptor in the failing canine myocardium. Circ Res 2001;89:599-606.

12 Yu J, Li W, Li Y, Zhao J, Wang L, Dong D, Pan Z, Yang B: Activation of beta(3)-adrenoceptor promotes rapid pacing-induced atrial electrical remodeling in rabbits. Cell Physiol Biochem 2011;28:87-96.

13 Sovari AA, Dudley Jr. SC: Reactive oxygen species-targeted therapeutic interventions for atrial fibrillation. Front Physiol 2012;3:311. 


\section{Cellular Physiology Cell Physiol Biochem 2016;38:514-530 \begin{tabular}{ll|l} 
DOI: 10.1159/000438647 & $\begin{array}{l}\text { O 2016 The Author(s). Published by S. Karger AG, Basel } \\
\text { www.karger.com/cpb }\end{array}$ \\
\hline
\end{tabular}}

Wang et al.: $\beta 3$ AR Agonist Contributes to Atrial Fibrillation

14 Alkaitis MS, Crabtree MJ: Recoupling the cardiac nitric oxide synthases: tetrahydrobiopterin synthesis and recycling. Curr Heart Fail Rep 2012;9:200-210.

15 Forstermann U, Sessa WC: Nitric oxide synthases: regulation and function. Eur Heart J 2012;33:829-837, 837a-837d.

16 Li Y, Li W, Gong Y, Li B, Liu W, Han W, Dong D, Sheng L, Xue J, Zhang L, Chu S, Yang B: The effects of cilizapril and valsartan on the mRNA and protein expressions of atrial calpains and atrial structural remodeling in atrial fibrillation dogs. Basic Res Cardiol 2007;102:245-256.

17 Swartz MF, Fink GW, Lutz CJ, Taffet SM, Berenfeld O, Vikstrom KL, Kasprowicz K, Bhatta L, Puskas F, Kalifa J, Jalife J: Left versus right atrial difference in dominant frequency, $\mathrm{K}(+)$ channel transcripts, and fibrosis in patients developing atrial fibrillation after cardiac surgery. Heart Rhythm 2009;6:1415-1422.

18 Sanders P, Berenfeld O, Hocini M, Jais P, Vaidyanathan R, Hsu LF, Garrigue S, Takahashi Y, Rotter M, Sacher F, Scavee C, Ploutz-Snyder R, Jalife J, Haissaguerre M: Spectral analysis identifies sites of high-frequency activity maintaining atrial fibrillation in humans. Circulation 2005;112:789-797.

19 Zhao J, Li J, Li W, Li Y, Shan H, Gong Y, Yang B: Effects of spironolactone on atrial structural remodelling in a canine model of atrial fibrillation produced by prolonged atrial pacing. Br J Pharmacol 2010;159:15841594.

20 Khan M, Mohan IK, Kutala VK, Kumbala D, Kuppusamy P: Cardioprotection by sulfaphenazole, a cytochrome $\mathrm{p} 450$ inhibitor: mitigation of ischemia-reperfusion injury by scavenging of reactive oxygen species. J Pharmacol Exp Ther 2007;323:813-821.

21 Fukushima T, Nixon JC: Analysis of reduced forms of biopterin in biological tissues and fluids. Anal Biochem 1980;102:176-188.

22 Dessy C, Moniotte S, Ghisdal P, Havaux X, Noirhomme P, Balligand JL: Endothelial beta3-adrenoceptors mediate vasorelaxation of human coronary microarteries through nitric oxide and endothelium-dependent hyperpolarization. Circulation 2004;110:948-954.

23 Tagaya E, Tamaoki J, Takemura H, Isono K, Nagai A: Atypical adrenoceptor-mediated relaxation of canine pulmonary artery through a cyclic adenosine monophosphate-dependent pathway. Lung 1999;177:321332.

24 Donckier JE, Massart PE, Mechelen HV, Heyndrickx GR, Gauthier C, Balligand JL: Cardiovascular effects of beta 3-adrenoceptor stimulation in perinephritic hypertension. Eur J Clin Invest 2001;31:681-689.

25 Zhou S, Tan AY, Paz O, Ogawa M, Chou C-C, Hayashi H, Nihei M, Fishbein MC, Chen LS, Lin S-F, Chen P-S: Antiarrhythmic Effects of Beta3-adrenergic receptor stimulation in a canine model of ventricular tachycardia. Heart Rhythm 2008;5:289-297.

26 Wakili R, Voigt N, Kaab S, Dobrev D, Nattel S: Recent advances in the molecular pathophysiology of atrial fibrillation. J Clin Invest 2011;121:2955-2968.

27 Burstein B, Qi XY, Yeh YH, Calderone A, Nattel S: Atrial cardiomyocyte tachycardia alters cardiac fibroblast function: a novel consideration in atrial remodeling. Cardiovasc Res 2007;76:442-452.

28 Nattel S, Harada M: Atrial remodeling and atrial fibrillation: recent advances and translational perspectives. J Am Coll Cardiol 2014;63:2335-2345.

29 Iwasaki YK, Nishida K, Kato T, Nattel S: Atrial fibrillation pathophysiology: implications for management. Circulation 2011;124:2264-2274.

30 Nattel S, Burstein B, Dobrev D: Atrial remodeling and atrial fibrillation: mechanisms and implications. Circ Arrhythm Electrophysiol 2008;1:62-73.

31 Yue L, Xie J, Nattel S: Molecular determinants of cardiac fibroblast electrical function and therapeutic implications for atrial fibrillation. Cardiovasc Res 2011;89:744-753.

32 Burstein B, Nattel S: Atrial fibrosis: mechanisms and clinical relevance in atrial fibrillation. J Am Coll Cardiol 2008;51:802-809.

33 Burstein B, Comtois P, Michael G, Nishida K, Villeneuve L, Yeh YH, Nattel S: Changes in connexin expression and the atrial fibrillation substrate in congestive heart failure. Circ Res 2009;105:1213-1222.

34 Liu Y, Geng J, Liu Y, Li Y, Shen J, Xiao X, Sheng L, Yang B, Cheng C, Li W: beta3-adrenoceptor mediates metabolic protein remodeling in a rabbit model of tachypacing-induced atrial fibrillation. Cell Physiol Biochem 2013;32:1631-1642.

35 Schotten U, Neuberger HR, Allessie MA: The role of atrial dilatation in the domestication of atrial fibrillation. Prog Biophys Mol Biol 2003;82:151-162. 


\section{Cellular Physiology Cell Physiol Biochem 2016;38:514-530

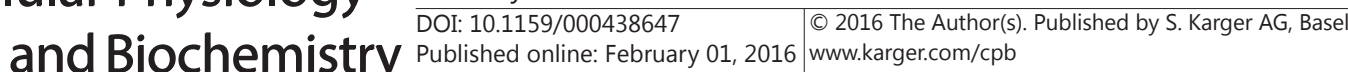

Wang et al.: $\beta 3$ AR Agonist Contributes to Atrial Fibrillation

36 Zou R, Kneller J, Leon LJ, Nattel S: Substrate size as a determinant of fibrillatory activity maintenance in a mathematical model of canine atrium. Am J Physiol Heart Circ Physiol 2005;289:H1002-1012.

37 Rochette L, Lorin J, Zeller M, Guilland JC, Lorgis L, Cottin Y, Vergely C: Nitric oxide synthase inhibition and oxidative stress in cardiovascular diseases: possible therapeutic targets? Pharmacol Ther 2013;140:239257.

38 Alkaitis MS, Crabtree MJ: Recoupling the cardiac nitric oxide synthases:Tetrahydrobiopterin synthesis and recycling. Curr Heart Fail Rep 2012;9:200-210.

39 Pollock J, Forstermann U, Mitchell J: Purification and characterization ofparticulate endothelium-derived relaxing factor synthase from cultured and nativebovine aortic endothelial cells. Proc Natl Acad Sci 1991;88:10480-10484.

40 Closs E, Scheld J, Sharafi M: Substrate supply for nitric-oxide synthase in macrophages and endothelial cells: role of cationic amino acid transporters. MolPharmacol 2000;57:68-74.

41 Simon A, Plies L, Habermeier A: Role of neutral amino acid transport and proteinbreakdown for substrate supply of nitric oxide synthase in human endothelial cells. CircRes 2003;93:813-820.

42 Heusch P, Aker S, Boengler K, Deindl E, van de Sand A, Klein K, Rassaf T, Konietzka I, Sewell A, Menazza S, Canton M, Heusch G, Di Lisa F, Schulz R: Increased inducible nitric oxide synthase and arginase II expression in heart failure: no net nitrite/nitrate production and protein S-nitrosylation. Am J Physiol Heart Circ Physiol 2010;299:H446-453.

43 Li J, Solus J, Chen Q Rho YH, Milne G, Stein CM, Darbar D: Role of inflammation and oxidative stress in atrial fibrillation. Heart Rhythm 2010;7:438-444.

44 Han W, Fu S, Wei N, Xie B, Li W, Yang S, Li Y, Liang Z, Huo H: Nitric oxide overproduction derived from inducible nitric oxide synthase increases cardiomyocyte apoptosis in human atrial fibrillation. Int J Cardiol 2008;130:165-173.

45 Skeberdis VA, Gendviliene V, Zablockaite D, Treinys R, Macianskiene R, Bogdelis A, Jurevicius J, Fischmeister $\mathrm{R}$ : beta3-adrenergic receptor activation increases human atrial tissue contractility and stimulates the L-type Ca2+ current. J Clin Invest 2008;118:3219-3227.

46 Gauthier C, Seze-Goismier C, Rozec B: Beta 3-adrenoceptors in the cardiovascular system. Clin Hemorheol Microcirc 2007;37:193-204.

47 Pott C, Brixius K, Bundkirchen A, Bolck B, Bloch W, Steinritz D, Mehlhorn U, Schwinger RH: The preferential beta3-adrenoceptor agonist BRL 37344 increases force via beta1-/beta2-adrenoceptors and induces endothelial nitric oxide synthase via beta3-adrenoceptors in human atrial myocardium. Br J Pharmacol 2003;138:521-529.

48 Brixius K, Bloch W, Pott C, Napp A, Krahwinkel A, Ziskoven C, Koriller M, Mehlhorn U, Hescheler J, Fleischmann B, Schwinger RH: Mechanisms of beta 3-adrenoceptor-induced eNOS activation in right atrial and left ventricular human myocardium. Br J Pharmacol 2004;143:1014-1022.

49 Watts V, Sepulveda F, Cingolani O, Ho A, Niu X, Kim R, Miller K, Vandegaer K, Bedja D, Gabrielson K, Rameau G, O'Rourke B, Kass D, Barouch L: Anti-hypertrophic and anti-oxidant effect of beta3-adrenergic stimulation in myocytes requires differential neuronal nos phosphorylation. J Mol Cell Cardiol 2013;62:817.

50 Moens AL, Claeys MJ, Wuyts FL, Goovaerts I, Van Hertbruggen E, Wendelen LC, Van Hoof VO, Vrints CJ: Effect of folic acid on endothelial function following acute myocardial infarction. Am J Cardiol 2007;99:476481.

51 Masano T, Kawashima S, Toh R, Satomi-Kobayashi S, Shinohara M, Takaya T, Sasaki N, Takeda M, Tawa H, Yamashita T, Yokoyama M, Hirata K: Beneficial effects of exogenous tetrahydrobiopterin on left ventricular remodeling after myocardial infarction in rats: the possible role of oxidative stress caused by uncoupled endothelial nitric oxide synthase. Circ J 2008;72:1512-1519. 